\title{
PARENT PERSPECTIVE BASED ON SALARY LEVEL OF INTRAPERSONAL INTELLIGENCE CHILD THROUGH SLEEPING COMPANIONS
}

\author{
${ }^{1}$ Salsabila Hasiana Tanjung, ${ }^{1}$ Suparno, ${ }^{3}$ Kamtini, \\ ${ }^{1}$ Yogyakarta State University, \\ ${ }^{3}$ Medan State University, \\ Email: hasianasalsabila@gmail.com,suparno_plb@uny.ac.id,kamtini@unimed.ac.id
}

\begin{abstract}
Education with affection will shape the intrapersonal intelligence of the child the better also. Personality of children in adulthood in general is the formation of personality and education obtained by children through the people around him, especially the family.Activities of storytelling is done before bed can also be said hypnoparenting which is education done at the time of the child before bed. At that time, the child will easily receive an education packed with stories containing advice. Education by way of telling stories to advise on children has been done by parents of ancient times. This study was conducted by giving a questionnaire and conducting simple interviews to randomly selected parents regardless of the background of their lives except the amount of salary they earn each month. This research uses quantitative descriptive method by interviewing selected fifty randomly selected parents. That parents who earn salary at point A or with income Rp 500,000 - Rp 2,000,000 more often accompany child sleep and assume it is important for children with the reason his son still want to be accompanied sleep and feel like accompany the child to sleep because it has been working all day outside.
\end{abstract}

Keywords: children, hypnoparenting. intrapersonal and salary

\begin{abstract}
Abstrak. Pendidikan dengan kasih sayang akan membentuk kecerdasan intrapersonal anak yang lebih baik juga. Kepribadian anak-anak di masa dewasa secara umum adalah pembentukan kepribadian dan pendidikan yang diperoleh anak-anak melalui orangorang di sekitarnya, terutama keluarga. Kegiatan mendongeng yang dilakukan sebelum tidur juga bisa dikatakan hypnoparenting yaitu pendidikan yang dilakukan pada saat anak sebelum tidur. Pada saat itu, anak akan dengan mudah menerima pendidikan yang dikemas dengan cerita yang berisi saran. Penelitian ini dilakukan dengan memberikan kuesioner dan melakukan wawancara sederhana kepada orang tua yang dipilih secara acak tanpa memandang latar belakang kehidupan mereka kecuali jumlah gaji yang mereka peroleh setiap bulan. Penelitian ini menggunakan metode deskriptif kuantitatif dengan mewawancarai terpilih lima puluh orang tua yang dipilih secara acak. Bahwa orang tua yang mendapat gaji di titik A atau dengan penghasilan $R p 500.000$ - Rp 2.000.000 lebih sering menemani tidur anak dan menganggap penting bagi anak dengan alasan anaknya masih ingin ditemani tidur dan merasa ingin menemani si kecil tidur karena sudah bekerja sepanjang hari di luar.
\end{abstract}

Kata kunci: kecerdasan intrapersonal, hypnoparenting, anak

\section{Introduction}

Parents are the first and most important educators for children. Parents of the main figure who must be responsible in family education. Because of the demands of work, there are parents who ultimately do not have the free time to provide child care, love, and care for children. Education in the family is the 
first and main education base. A harmonious and happy family situation will give birth to a child or good and responsible generations of successors. The role of parents should be the first person in laying the fundamentals of education for their children. With this, family life, especially the role of parents is the first educational environment that has an important role in determining and fostering the process of child development.

Many parents today who do not have time to accompany the child to sleep by giving advice or a funny story of a fairy tale before bed.Very interpersonal intelligence required in everyday activities, both at school and at home. Children are always in touch and need the help of others in every activity undertaken. Children live in a social environment that indirectly must be able to establish good relationships withothers.

Inextricable proximity between the child and the parent or with those around him will cause the child's intrapersonal intelligence to not develop properly, causing social tension. Although the social tension of children with family or people around it is not only due to lack of interaction but frequency of contact, personality differences, child rearing, and past relationship problems (Birditt, Miller, Fingerman dan Lefkowitz : 2009). Individual tension includes work / education, finance, household, lifestyle, and health. This study includes quantitative measures of this tension allowing for comparison of parental and adult ratios of children from the intensity of individual relationships and tensions. So also in school, children should be able to build good relationships with friends and teachers, because with it the child will be easily accepted and able to adjust to the social environment.

As the child begins to grow and develop, he will constantly try and find and establish his identity, the child wants to know who he is and how to adjust to his world. In the process of growth and learning process children will inevitably meet with people who transcend themselves in appearance, ability and talent Children at an early age who do not get the primary education and affection from parents, then the child will find another comfortable place that does not necessarily provide welfare, care, upbringing and guidance in accordance with the needs of children. The formation of the boundary between "self" and "others" is determined by the first three years and the acquisition of affection, recognition, encouragement, and role models. There are at least ten intrapersonal intelligence indicators.

The good personality that the child possesses, is proof that the intrapersonal intelligence of the child is good. Education with affection will shape the intrapersonal intelligence of the child the better also. Children with dominant intrapersonal intelligence also have the ability to find ways or ways of expressing feelings and thoughts appropriately. When faced with complicated problems, he is also able to motivate himself to immediately rise up and push yourself to achieve goals or targets themselves. The core component of intrapersonal intelligence is the ability toaccurately understand oneself including strength and self-limitation, awareness of mood, purpose, motivation, temperament, and desire, and self-discipline, understanding, and self-respect.

Personality of children in adulthood in general is the formation of personality and education obtained by children through the people around him, especially the family. If at an early age the child does not get a chance to get education and the formation of the right personality, then the child in his adult life will be the wrong child in the behavior of his personality. In a family, the interaction between parent and child involves a certain behavioral pattern of the parent. Pattern of interaction between parent and child in a family to teach, guide and educate with a specific purpose called parenting style. Parenting style is the way parents express thoughts and feelings in the interactions between parents and their children.

Mistaken in the intrapersonal it will lead to negative behavior in children and will experience stress that can cause negative 
impacts that can affect to a wider area, such as trouble with sleep,anger, depression, suicide, teenage pregnancy, poor performance in school, frequent illness and lack of selfconfidence (Groves : 2004) . It will not immediately appear the behavior at that moment, but it can happen in the future child. As in the events that occurred on 27 April 2013 in Bekasi reported by TV One Evening News that "a first grader of a primary school became a suspect in the murder of a six-year-old friend of his match. Suspected of murder caused by a dispute because the victim owes Rp.1000, - on thesuspect (Margaretha : 2013). Cases done by minors indicate that the intrapersonal intelligence that the child has does not develop properly. It can be influenced by children not getting education and affection that suits their needs.

Thus the researcher wanted to see how the effect of salary level obtained by parents on the importance of their main role to intrapersonal intelligence of children and children raised in busy families, as many as $40.19 \%$ of children who experience stress (Sorensen : 1993). The success of the parent's role in the education of the child through telling a child before bedtime is expected through the telling tale, the child receiving the counseled advice will be able to reduce the crime committed by the child. Activities of storytelling is done before bed can also be said hypnoparenting which is education done at the time of the child before bed. Hypnoparenting is one of the parenting techniques by utilizing hypnosis techniques. Hypnoparenting is a combination of two words, namely "hypnosis" and "parenting". By using hypnosis techniques in parenting, you can suggest a child to do the positive things you want. Children can also receive lessons from parents more easily. The main principle of hypnoparenting is to say suggestive words repeatedly to the child when the child's brain is in Alpha (8-12 Hz). When the child is in a relaxed state or rest (sleepy and the eyes begin to close) that's the child's brain condition in Alpha waves. When the brain works in Beta waves $(12-19 \mathrm{~Hz})$, the brain is alert, while in sleep the brain is in the Theta $(4-8 \mathrm{~Hz})$ waves. At that time, the child will easily receive an education packed with stories containing advice.

Hypnoparentingcanbedonesystematically and very simply. Hypnoparenting is very easy to run when we know the technique and right when running it. This is very effective if parents provide all the environmental facilities that are conducive to the growth of programs that have been suggested. Its success can be seen directly in behavior that has changed as it has been suggested. The implementation of this hypnoparenting requires only parent commitment, environmental conditions, and a balanced chat that makes parents understand what is in the child's mind. The principle embedded in hypnoparenting is that all that is done or said by the parent is essentially a hypnosis, because it will be patterned in the mind of the child. Education by way of telling stories to advise on children has been done by parents of ancient times. Children who get the right education and affection then the child's intelligence will also develop properly. children's intrapersonal intelligence related to social and emotional development of children is very important to be developed because it becomes one of the capital for children to plunge into their social world.

Hypnoparenting education is not obtained by children because parents have a complex busyness. Children should receive education from parents who should be responsible in providing education and care based care in accordance with Law no. 23 of 2002, that the right of the child is theresponsibility of the State, government, community, family and parents and Law no. 4 Year 1979, affirming the child is entitled to the welfare, care, care and guidance based on affection both in his family and in special care to grow and develop properly. Early children who are not educated and caring with affection will make children look for an environment that makes children feel comfortable, regardless of whether the environment is safe or not for them. The positive upkeep and a supportive environment 
help create the foundations for the development of human existence, intellectually, emotionally and physically(Campbell : 2006).

Increased social behavior tends to be most prominent in childhood. This is due to the increasing social experience in children, the children studying the other's views on their behavior and how those views influence the level of acceptance of peer groups, but there are some non-social or antisocial behaviors. With early education and good intellectual ability of children, will affect the social skills of children. Children do not will be confused to adjust to the social environment outside the home and children more familiar with the social environment outside the family if provided with early social skills with the right stimulation.

Children will naturally continue to learn, and early child learn through what children see. In the social learning perspective there are four processes that lead to the formation of a behavior in the social learning process ie differential association, definition, imitation, and differential reinforcement (Margaretha : 2013). A person will commit a criminal act if he or she is in touch with the people who do, model and support the behavior. According to the Secretary General of Komnas PA (Arjawinangun : 2014)that in 2013, about 5000 children are languishing in jail and some have been convicted of committing a crime. It shows that $0.001 \%$ of Indonesian children of 52 million childrendo not have well-developed intrapersonal intelligence (UNICEF Indonesia : 2012). That is, saying the child will be a person who does not respect the rules, has no ethics and morals that should have developed according to his age (Syakir : 2014). The lack of a person having social skills leads to behavioral difficulties in school,misbehavior, lack of attention, peer rejection, emotional difficulties, bullying, difficulty in friends, aggressiveness, problems in interpersonal relationships, poor self-concept, academic failure, concentration difficulties, isolation from peers, and depression.Aspects that affect the development of children, especially cognitive, social and emotional development among them are health, home conditions, age and family economic conditions (Spencer and Blades : 2005). Increased social behavior tends to be most prominent in childhood.

In adaptation to the environment, interpersonal intelligence is necessary in building positive relationships with others. The environment in which children grow certainly has some impact on the type of personality characteristics of the child. If families have high conflicts, and children are attracted to many arguments and disagreements, they will most likely have conflicting personalities, as they get older. In addition, if a family does not have any structure in the household, children will be far more impulsive and may get into trouble more often than children from a structured family.Parents who have a short duration to interact with children tend to have higher levels of stress than parents who often have close interaction with children (Neece, Green and Baker : 2012). Children who come from parents who have high levels of stress more have problems of development, especially on personal development. Intrapersonal intelligence involves thinking and feeling. Intrapersonal intelligence is the ability to understand oneself and act on them. Thisintelligence includes the ability to accurately understand oneself (strength and self-limitation), awareness of mood, intent, motivation, temperament, and desire, and selfdiscipline, understanding and self-respect. Negative behaviors performed by children such as arguing, lazy, lying, stealing and hitting are also called Alligator's brain which can be controlled by doing hypnoparenting method (Faeni : 2012). If the early child who is in the golden period does not get the education and care that one can do by telling the child before bed or using the Hypnoparenting method. then the development of children's intrapersonal intelligence will not develop in accordance with expectations that result in a criminal act and behavior committed to someone in adolescence or adult, basically been formed from an early age.Interpersonal skillsis the ability to interact 
with others such as understanding others and building relationships with others.The interpersonal intelligence of the child can be seen in the child's sensitivity to peer feelings, the ability to motivate and encourage others, the friendliness of attitudes and social skills, the tendency to cooperate with others and share, the ability to mediate conflict, and other matters of a nature related to others.

The effective time of doing hypnoparenting needs to be understood because by understanding it, it will be able to enter the suggestion at the right time. The time that is when invites children to pray, relaxed atmosphere, and soft voice so that created calm and children are easily hypnotized, just before waking up the condition is similar to the bedtime and while carrying, in the form of cradle, this is effective time dpaat used to hypnotize a child. His thoughts and feelings are at the lowest level(Lucy : 2012). Through singing, a soft and slow song will make the child hypnotized more easily. Storytelling is a method of hypnosis that is also effective. Meaningful tales and motivated children will make it easier to get into the subconscious mind of the child.

\section{Reserach Method}

This study was conducted by giving a questionnaireand conductingsimpleinterviews to randomly selected parents regardless of the background of their lives except the amount of salary they earn each month. The parents who responded to the questionnaire provided the researchers conducted a simple interview about the contents of the given questionnaire. Parents who become respondents are divided into three types based on the amount of salary, following the translation:

Table 1. Classification of Salary Levels of Parents

\begin{tabular}{cc}
\hline Symbol & \multicolumn{1}{c}{ Salary } \\
\hline A & Rp $500.000-$ Rp 2.000.000 \\
B & Rp. 2.000.000-Rp 3.500.000 \\
C & Rp 3.500.000-Rp 4.000.000 \\
\hline
\end{tabular}

Parents who are given the symbol A is a parent who earns a monthly salary of about Rp 500,000 - Rp 2,000,000, parents who are given the symbol $\mathrm{B}$ is a parent who get a salary of $\mathrm{Rp} 2,000,000$ - Rp 3,500,000 and parents are given the symbol $\mathrm{C}$ is a parent who earns a salary per month of Rp 3,500,000 - Rp $4,000,000$.

List of questions on the questionnaire that was passed on to the parents.

1. Do you accompany your child before going to sleep?

a. Yes, often b. Yes, Rarely c. Never

2. How important is accompanying child before sleep?
a. Very Important
b. Indifferent
c. Not Important

3. At the final age how many children are accompanied by sleep?
a. 3-4 Years
b. 4-5 Years
c. 5-6 Years

4. What is the dominant behavior in children?
a. Merciful
b. Against
c. Courageous

5. Child closer to whom?
a. Mother
b. Father
c. Other

Respondents filled in the questionnaire given, then the researchers conducted a simple discussion with parents based on the results of the questionnaire that they fill. Here are the results of filling in the questionnaire: 
Table 2. Results of Questionnaire Based on Parent / Respondent's Experience

\begin{tabular}{|c|c|c|c|}
\hline 1. Do you accompany your child before going to sleep? & $\begin{array}{l}\text { Yes, Often } \\
(64 \%) \\
\text { A. }- \\
\text { B. } 8 \% \\
\text { C. } 56 \%\end{array}$ & $\begin{array}{l}\text { Yes, Rarely } \\
(22 \%) \\
\text { A. } 12 \% \\
\text { B. } 6 \% \\
\text { C. } 4 \%\end{array}$ & $\begin{array}{l}\text { Never } \\
(20 \%) \\
\text { A. } 6 \% \\
\text { B. } 8 \% \\
\text { C. - }\end{array}$ \\
\hline 2. How important is accompanyi-ng child befor sleep? & $\begin{array}{l}\text { Very Important } \\
(66 \%) \\
\text { A. - } \\
\text { B. } 6 \% \\
\text { C. } 60 \%\end{array}$ & $\begin{array}{l}\text { Indiffernt } \\
(34 \%) \\
\text { A. } 24 \% \\
\text { B. } 10 \% \\
\text { C. }-\% \%\end{array}$ & $\begin{array}{l}\text { Not Important } \\
- \\
\text { A. - } \\
\text { B. - } \\
\text { C. - }\end{array}$ \\
\hline 3. At the final age how many children are accompanied by sleep? & $\begin{array}{l}\text { 3-4Years } \\
(16 \%) \\
\text { A. } 16 \% \\
\text { B. - } \\
\text { C. - }\end{array}$ & $\begin{array}{l}\text { 4-5 Years } \\
\quad(52 \%) \\
\text { A. } 24 \% \\
\text { B. } 12 \% \\
\text { C. } 16 \%\end{array}$ & $\begin{array}{l}5-6 \text { Y e a r s } \\
\quad(32 \%) \\
\text { A. } 6 \% \\
\text { B. } 8 \% \\
\text { C. } 18 \%\end{array}$ \\
\hline 4. What is the dominant behavior in children? & $\begin{array}{l}\text { Merciful } \\
(56 \%) \\
\text { A. } 4 \% \\
\text { B. } 12 \% \\
\text { C. } 40 \%\end{array}$ & $\begin{array}{l}\text { Against } \\
(26 \%) \\
\text { A. } 24 \% \\
\text { B. } 2 \% \\
\text { C. }-\end{array}$ & $\begin{array}{l}\text { Courageous } \\
\qquad(18 \%) \\
\text { A. } 2 \% \\
\text { B. } 4 \% \\
\text { C. } 12 \%\end{array}$ \\
\hline 5.Child closer to whom? & $\begin{array}{l}\text { Mother } \\
(58 \%) \\
\text { A. } 8 \% \\
\text { B. } 26 \% \\
\text { C. } 24 \%\end{array}$ & $\begin{array}{l}\text { Father } \\
(34 \%) \\
\text { A. } 4 \% \\
\text { B. } 4 \% \\
\text { C. } 28 \%\end{array}$ & $\begin{array}{l}\text { Other } \\
(32 \%) \\
\text { A. } 6 \% \\
\text { B. - } \\
\text { C. - }\end{array}$ \\
\hline
\end{tabular}

Based on the results of questionnaires and simple interviews, many parents who still think accompanying children to sleep is an important thing done by children, but there are some parents who also think it only makes children become spoiled and not independent.

\section{Result and Discussion}

Based on the data, parents who earn with symbolic $\mathrm{C}$ and catch up more often tend to accompany their children before bed. This is because the parents want to menemeni children who can not be given time in the morning until the afternoon, so do not want to lose the moment with the child.And parents in this class choose not to often accompany their children to sleep at the age of 5-6 years.

Parents who earn on symbolic A, prefer not to be too accompanying their children to sleep because it is only to make the child does not become independent and courageous.

According to the answers to the behavior of children, the children of parents $\mathrm{B}$ and $\mathrm{C}$ are more likely to have bold and pleasant behavior. whereas in children of parents who earn income on symbol A tends to be stubborn, not too familiar and tends to fight, for a matter of courage that is like the purpose of parental decisions A there is only one child who has a brave nature based on the answers kuisoner.

\section{Conclusion and Suggestion}

Parents who earn enough money based on the results of this study show more care about the attachment between children and parents in building and fostering good character for children. Despite the busy busyness, the parents are still working on the time to remain able to accompany their children to sleep while doing a warm interaction with the child so that grows a sense of comfort in children and awaken the character guidance through hypnoparenting is done.

This should be done for all parents, from salaries in small groups to large. It seems that parents, especially those with a background with a salary in the small group, need more education socialization for parents about the child's personal. So that can be closer to the child and easy in growing children's intrapersonal intelligence. 


\section{References}

Arjawinangun, Kamarudding Bogja. 2014. 5000 Anak Mendekam di Penjara. Viahttp://metrosindonews.comon 14 Februari 2016 at 03:30 pm.

Birditt, Kira S. Miller, Laura M. Fingerman, Karch.

L. Lefkowitz, Evas. (2009). Tensions in the Parent and Adult Child Relationship: Links to Solidarity and Ambivalence. Psychol Aging Journal.https://www.ncbi.nlm.nih.gov/pmc/ articles/PMC2690709/Campbell, Linda. 2006. Metode Praktis.

Pembelajaran Berbasis Multiple Intelligences. Depok : Intuisi Pers.

Faeni, Dewi. (2012). Hypnoparenting. Jakarta: Mizan Pustaka.

Groves, Dawn. (2004). Stress Reduction Fpr Busy People. California : New York Library.

Lucy. Bunda. (2012). 5 Menit Menguasai Hypnoparenting. Penebar Plus : Jakarta.

Margaretha. 2013. Kejahatan Anak. Downloaded via https: //psikologiforensik, com on February 15, 2016 at 07:25 pm.

Neece, C. L., Green, S. A., \& Baker, B. L. (2012).

Parenting stress and child behavior problems: A transactional relationship across time. American Journal on Intellectual and Developmental Disabilities, 117(1), 48-66. https://doi. org/10.1352/1944-7558-117.1.48.

Sorensen, Elanie Shaw. (1993). Childern's Stress and Coping : A Family Perspective. London: Spring Street.

Spencer, Christoper. Blades, Mark. (2005). Children and Their Environments : Learning, Using, and Designing Spaces. New York : Cambridge University Press.

Syakir, Septian el. 2014. Islamic HypnoParenting: Mendidik Anak Masa Kini Ala Rasulullah. Jakarta : KAWAHmedia.

UNICEF Indonesia. 2012. Indonesia : Laporan Tahunan 2012-Unite For Children. via www. unicef.org on 18 Februari 2016 at 08.04 pm. 